\title{
Preface and acknowledgments
}

I did not begin my professional life under the banner of International Political Economy (IPE). All of my formal university training, way back in the dimly remembered past, was in conventional economics - a much more prosaic choice. I knew from the start of my studies that I wanted to specialize in economics. More to the point, I wanted to specialize in international economics. As I have often joked to my students, I wanted to see as much of the world as possible; and of all the branches of the economics discipline, international economics seemed to promise the greatest opportunity for travel. At the time I had never even heard of something called political economy. It was only after I took my first academic post, nearly six decades ago, that I began to broaden my ambitions to encompass not just the economics but also the politics of international affairs. An odyssey had begun. It has been a most satisfying journey.

My transition to IPE did not take place quickly. How could I convert to something that did not even yet exist as a recognized field of study? There were of course versions of IPE to be found at the time in Latin America and elsewhere in the developing world, in the writings of Marxists and others of a more critical persuasion. Scholars like these had little difficulty seeing connections between economics and politics in the global capitalist system. But in the Western social science canon in which I was trained, there was as yet no formal disciplinary home for what today we call political economy. The established disciplines of political science and economics had long been firmly separated, with hardly a word passed between them. There was certainly no regular communication between them about international affairs. I recall that in the one political science course that I took as an undergraduate, an introduction to world politics, there was rarely any mention at all of the "low politics" of economic relations; the lectures were all about military security and the threat of nuclear weapons. Conversely, in none of my many economics courses did I ever hear anything about political processes or institutions; classes were all about resource efficiency, market stabilization, and the elusive hunt for Pareto optimality. The twain never met. 
But I was lucky. As it turned out, I was not alone. In the late 1960s and early 1970s, a pioneering generation of scholars on the two sides of the Atlantic was just starting to explore the diverse political dimensions of the world economy. These included giants like Bob Gilpin, Peter Katzenstein, Bob Keohane, Charlie Kindleberger, and Susan Strange. A new field of study called International Political Economy was beginning to emerge (or, as some would have it, re-emerge).

Until exposed to pioneering efforts like those, my own career path remained unremarkable. I studied conventional international economics under the tutelage of Peter Kenen, one of the top international economists of the day. Then, with my new doctorate in hand, I worked for two years as a research economist at the Federal Reserve Bank of New York; and even after beginning my teaching career at Princeton University in 1964, I continued to stick to the standards of orthodox economics. A turning point came in 1968, when I arrived in London to spend a sabbatical year writing a book on the British pound sterling (Cohen 1971). If you're going to research the pound, I was told, I must meet Strange, who at the time was also working on a book on sterling - published not long after under the title Sterling and British Policy (Strange 1971). So I sought her out. When we got together, I dutifully told her about my plan to do a strictly economic cost-benefit calculus of sterling's role as an international currency. "Oh, Jerry," Susan replied, squinting at me through hooded eyes, "you can't possibly write about the pound without talking about the politics, too" - a remonstration that she would subsequently repeat to me on every possible occasion. At the time I resisted, with a stubbornness born of my conventional economics training. The loss was mine. Her book, a monumental study, turned out to be far more interesting.

Ultimately, Strange's message did get through. By the time I got back to the United States, I was determined - thanks, in good part, to her - to dip my toe into this alluring new current of scholarship. In quick order that led me to produce two eager sallies into the emerging field. The first was The Question of Imperialism: The Political Economy of Dominance and Dependence (1973), written largely in response to persistent queries from my students about the seeming inequities of the global economic system. The second was a successor to my sterling book, Organizing the World's Money (Cohen 1977), which may legitimately be described as the first fully integrated exploration of the economic and political dimensions of global monetary governance. These two works marked the completion of my intellectual transformation - "one of the rare cases 
of an economist," one observer wrote of me, "who came in from the cold of the dismal science" (Underhill 2000: 811). Ever since, IPE has been my scholarly home.

Over time, however, the home provided to me by IPE seems to have fallen increasingly into disrepair. Not everyone will agree, of course. For many in the field, IPE is thriving as never before. But I dissent. Over the years, I have tried to learn as much as I could about the field, both its strengths and its weaknesses. Unlike a good number of my American colleagues, I have also made a determined effort to inform myself about versions of IPE to be found in other parts of the world - not just locally in the United States, where I happened to study - and have even written about them.

First came International Political Economy: An Intellectual History (Cohen 2008), in which I sought to provide a brief history of the field since the late 1960s. The coverage of that volume was deliberately limited to the English-speaking world - otherwise known as the "Anglosphere" - defined here to include mainly the United States, Canada, the British Isles, and the Antipodes. It was also limited to what might be considered mainstream conceptions of IPE in the Anglosphere, excluding heterodox outliers. Though my intention was to broaden horizons by going beyond a single orthodoxy, I was surprised to find the book criticized for being, if anything, unduly narrow in its coverage. In the words of one commentary, "Cohen's account excludes too much ... These exclusions amount to omitting a considerable part of what is taught and written in IPE" (Leander 2009: 322-3). Upon reflection, I found I had to agree. Hence a few years later I produced a second book, Advanced Introduction to International Political Economy, now in its second edition (Cohen 2019), which may be considered as something of a sequel to my earlier Intellectual History. Advanced Introduction took us much further afield, broadening perspectives even more. My aim in that volume was to provide a comprehensive tour d'horizon of IPE as it exists across the globe.

Regrettably, though, the more I have learned about IPE in its many guises, the more unhappy I find myself with what our area of inquiry has gradually become. Some may feel that is simply because I have grown old and cranky. There could be some truth to that. (My wife, for one, might heartily concur.) Others will accuse me of pessimism, perhaps even dank paranoia. But mine is not a cri de coeur of despair. I am more inclined to see myself as offering a bit of light, a realistic way forward, at a moment of gathering darkness. 
To be blunt: I am convinced that our train has gone off its tracks, moving in directions that are misguided if not absolutely mindless. Pathologies beset the field that could threaten its vitality, even its very existence. Starting with an essay published in 2007, "The Transatlantic Divide: Why are American and British IPE So Different?" (Cohen 2007) and continuing with my Intellectual History and Advanced Introduction and a slew of articles, I have mounted a long-running campaign to persuade my scholarly colleagues to open their minds to reconsider the substance and purpose of what we do - in short, to rethink IPE. This book continues that effort.

Rethinking International Political Economy summarizes in comprehensive fashion my judgment of where the field of IPE has gone wrong and where it should instead be heading. The title is not meant to suggest that we must wipe the slate clean and start over. There is much of value in the field that can and should be preserved. Nor does it mean rewinding to some purported Golden Age. There never was such a thing. Rethinking means building on what has already been accomplished while making course corrections where needed. It is not too late to save IPE from itself.

But will anyone listen? Back when I was just getting started on this project, a well-established senior colleague advised me to stop wasting my time. His intentions were honorable. No one will care, he warned. Minds are already made up and are unlikely to be amenable to revision. Too much time and effort have been invested in the status quo. I know from bitter experience that my kind friend could be right. There are indeed many in the field who see no reason at all for significant change. Once, after I explained some of my ideas, another eminent colleague responded, "Get serious, Jerry." Well, I am serious, and I like to think that there are also many fellow scholars who might share my concerns. I can only hope that my arguments here will be given a fair hearing.

My intended audience comprises two groups in particular. First are my scholarly peers in universities and research institutions around the world, whose interests encompass or border on some aspect of IPE. These are the people who, by their publications, teaching, and other professional activities, collectively define the parameters of the field as it exists today. And second are the many students of IPE in classrooms across the globe. These are the souls who will define the field as it will be practiced tomorrow. Modestly, my ambition is to change minds in the first group and to help shape minds in the second. I make no secret of my desire to shake things up a bit. My aim is to be disruptive - but also constructive. 
A book like this would hardly have been possible without the generous help and encouragement of a large number of friends and colleagues, though of course none of them can be held responsible for anything that I say here. I am indebted to them all for their support.

I am especially grateful to seven friends who kindly consented to read the entire manuscript of this book while it was still in preparation, providing valuable critiques. These were Greg Chin, Bob Denemark, Randy Germain, Jeremy Green, Andrew Walter, Hongying Wang, and Matthew Watson. I am also deeply indebted to others who read one or more of the chapters in draft, including Jeff Chwieroth, Miles Kahler, Peter Katzenstein, Bob Keohane, David Lake, Matthias Matthijs, Craig Murphy, and Kevin Young.

These friends and a substantial number of other colleagues also graciously consented to respond to my efforts when this project was just getting under way to solicit their views on the issues I intended to address. In all, some 54 fellow scholars shared their thoughts with me - a broad cross-section of the discipline including both junior and senior researchers and representing a range of nationalities and theoretical orientations. At various points in the text some of these colleagues are quoted. But their words are offered without attribution in an effort to safeguard their anonymity. In all such cases, comments and observations are reproduced faithfully from private communications. These Good Samaritans include Leslie Armijo, David Bearce, Jacqueline Best, Steve Best, Mark Blyth, Lawrence Broz, Christopher Chase-Dunn, Stephen Chaudoin, Jeff Chwieroth, Bob Denemark, Jeff Frieden, Randy Germain, Jeremy Green, Mark Hallerberg, Shahar Hameiri, Eric Helleiner, Randy Henning, Nicolas Jabko, Joe Jupille, Miles Kahler, Saori Katada, Peter Katzenstein, Ryan Katz-Rosene, Bob Keohane, Jonathan Kirshner, David Lake, David Leblang, Ed Manfield, Matthias Matthijs, Dan McDowell, Kate McNamara, Daniel Mügge, Craig Murphy, Andreas Nölke, Robert O’Brien, Miguel Otero-Iglesias, Lou Pauly, Tom Pepinsky, Lucia Quaglia, Thomas Risse, Bill Robinson, Nita Rudra, Mark Schwartz, Ben Selwyn, Jason Sharman, Tim Sinclair, David Steinberg, Federico Steinberg, Geoffrey Underhill, Andrew Walter, Hongying Wang, Matthew Watson, Wil Winecoff, and Kevin Young.

Portions of this manuscript were presented and discussed in colloquia at Waterloo University (Canada) and FLACSO Quito (Ecuador). The 
comments and suggestions I received from participants at these events were especially valuable. Useful observations also came from two students in the Global Studies program at the University of California Santa Barbara, Brett Aho and Mariah Miller.

In addition, I benefitted greatly from the research assistance of several of my students in the UCSB Political Science Department, including Vashnishtha Doshi, Andrew Johnson, Eric Stein, Ingmar Sturm, and Annjulie Vester. Their industrious support is also gratefully acknowledged.

This book is dedicated to the memory of Peter Kenen and Charlie Kindleberger, two giants of the economics profession whose intellect and ideas have inspired me for more than half a century.

Finally, my sincere thanks go to anyone out there who does actually bother to read what I have to say in the following pages. You will find that my tone is provocative. That is deliberate. Though I do not mean to be shrilly polemical, I do hope to shake people out of their comfort zone. A little iconoclasm can go a long way. 


\section{REFERENCES}

Cohen, Benjamin J. (1971), The Future of Sterling as an International Currency (London: Macmillan).

Cohen, Benjamin J. (1973), The Question of Imperialism: The Political Economy of Dominance and Dependence (New York: Basic Books).

Cohen, Benjamin J. (1977), Organizing the World's Money: The Political Economy of International Monetary Relations (New York: Basic Books).

Cohen, Benjamin J. (2007), "The Transatlantic Divide: Why are American and British IPE So Different?" Review of International Political Economy 14:2, 197-219.

Cohen, Benjamin J. (2008), International Political Economy: An Intellectual History (Princeton, NJ: Princeton University Press).

Cohen, Benjamin J. (2019), Advanced Introduction to International Political Economy, revised 2nd edition (Cheltenham, UK and Northampton, MA, USA: Edward Elgar Publishing).

Leander, Anna (2009), "Why We Need Multiple Stories about the Global Political Economy," Review of International Political Economy 16:2, 321-8.

Strange, Susan (1971), Sterling and British Policy: A Political Study of an International Currency in Decline (London: Oxford University Press).

Underhill, Geoffrey R.D. (2000), "State, Market, and Global Political Economy: Genealogy of an (Inter?) Discipline," International Affairs 76:4, 805-24. 